Al-Madrasah: Jurnal Ilmiah Pendidikan Madrasah Ibtidaiyah

Vol. 6, No. 1, 2022

DOI 10.35931/am.v6i1.780

P-ISSN: 2620-5807; E-ISSN: 2620-7184

\title{
PERANCANGAN SILABUS ESP PROGRAM STUDI PENDIDIKAN GURU MADRASAH IBTIDAIYAH DI UIN ANTASARI BANJARMASIN
}

\author{
Riinawati \\ UIN Antasari Banjarmasin, Kalimantan Selatan, Indonesia \\ riinawati@uin-antasari.ac.id
}

\begin{abstract}
Abstrak
Tujuan dari penelitian ini adalah untuk merancang silabus esp bagi mahasiswa semester I Program Studi Pendidikan Guru Madrasah Ibtidaiyah UIN Antasari Banjarmasin. Desain penelitian yang digunakan dalam penelitian ini adalah Research and Development $(R \& D)$ dengan menggunakan model ADDIE. Dalam penelitian ini, tiga ahli dilibatkan untuk memvalidasi produk. Sebagai produk dari penelitian ini, perancangan silabus bahasa Inggris untuk Program Studi Pendidikan Guru Madrasah Ibtidaiyah semester I di IAIN Palopo meliputi beberapa komponen: (1) tujuan pembelajaran bahasa Inggris untuk Program Studi Pendidikan Guru Madrasah Ibtidaiyah adalah guru SD/Madrasah Ibtidaiyah dan untuk mengkomunikasikan baik lisan maupun tulisan menggunakan bahasa Inggris di Pendidikan Guru Madrasah Ibtidaiyah. (2) materi pembelajaran: Materi bahasa Inggris adalah bahasa Inggris dasar dan kosa kata termasuk part of speech, auxiliary verb (to be, to do, dll). Materi Madrasah Ibtidaiyah meliputi pengenalan diri, salam, keluarga, rumah, sekolah, makanan dan minuman, binatang, mengungkapkan perasaan, waktu bercerita, profesi, dan fabel. (3) metodologi pembelajaran adalah pembelajaran berbasis tugas. (4) media pembelajaran berupa: video, gambar, audio, dan buku cerita. Instrumen yang digunakan dalam penelitian ini adalah angket untuk analisis kebutuhan dan lembar observasi untuk tiga validator ahli dan persepsi siswa. Hasil penelitian menunjukkan bahwa berdasarkan validasi ahli dan persepsi siswa serta hasil rancangan uji coba, produk penelitian ini layak diterapkan pada siswa Program Studi Pendidikan Guru Madrasah Ibtidaiyah semester I sebagai sekolah dasar silabus untuk kursus bahasa Inggris. Silabus yang dirancang dari penelitian ini akan bermanfaat bagi dosen Bahasa Inggris dalam mengajar Bahasa Inggris untuk Program Studi Pendidikan Guru Madrasah Ibtidaiyah, khususnya mahasiswa semester pertama.
\end{abstract}

Kata kunci-desain, pendidikan bahasa inggris, madrasah ibtidaiyah

Al-Madrasah: Jurnal Ilmiah Pendidikan Madrasah Ibtidaiyah

Vol. 6, No. 1, Januari-Maret 2022 
Riinawati : Perancangan Silabus ESP Program Studi Pendidikan Guru Madrasah Ibtidaiyah di UIN Antasari Banjarmasin

\section{PENDAHULUAN}

Bahasa Inggris untuk Keperluan Khusus mengacu pada pengajaran bahasa Inggris kepada pelajar tertentu yang belajar untuk mayoritas tertentu. Ini memberikan pengajaran bahasa Inggris yang dipimpin terkait dengan kebutuhan pelajar di sebagian besar mereka. Bahasa Inggris untuk Keperluan Khusus adalah istilah umum yang menyampaikan bahasa Inggris kepada siswa yang sedang mempelajari bahasa tersebut untuk pekerjaan tertentu atau alasan terkait studi ${ }^{1}$. Selain itu, Bahasa Inggris untuk Keperluan Khusus lebih ditekankan kepada siswa yang mempelajari keterampilan khusus dalam studi mereka dan berkontribusi dalam belajar bahasa Inggris untuk bakat tertentu. Bahasa Inggris untuk tujuan tertentu adalah pendekatan yang didasarkan pada kebutuhan pembelajar atau bukan produk bahasa ${ }^{2}$.

Silabus adalah pengembangan kurikulum yang menggambarkan kompetensi yang diperlukan dan kompetensi yang perlu dicapai, pokok-pokok, dan uraian materi yang perlu dipelajari siswa. Silabus sebagai pengembangan kurikulum dan pembelajaran dalam pelaksanaannya oleh pendidik dijabarkan dalam rencana dan pelaksanaan pembelajaran untuk menilai hasil belajar ${ }^{3}$. Pendidik mengkaji dan mengembangkan silabus secara berkesinambungan dengan memperhatikan dan mempertimbangkan hasil evaluasi melalui refleksi dan melalui penelitian tindakan kelas dan evaluasi hasil belajar melalui tes dengan prosedur dan standar yang benar ${ }^{4}$.

Silabus didefinisikan sebagai dokumen yang terdiri dari topik atau bagian yang tercakup dalam mata pelajaran tertentu. Hal ini dibuktikan dengan adanya papan ujian dan dibuat oleh para ahli. Para ahli bertanggung jawab atas

\footnotetext{
${ }^{1}$ Ahwy Oktradiksa, "Islamic Learning in English Academic Purpose," no. May (2016): 1-151.

${ }^{2}$ Dewi Selviani Yulientinah, Rukmi Juwita, and Widia Resdiana, "Identifikasi Analisis Kebutuhan Pembelajaran Bahasa Inggris (Non Program Studi Bahasa Inggris) Pada Mata Kuliah Bahasa Inggris Khusus/ English For Specific Purposes (ESP) Di Program Studi D4 Akuntansi Keuangan Politeknik Pos Indonesia," Competitive 15, no. 1 (2020): 1-11, https://doi.org/10.36618/competitive.v15i1.625.

${ }^{3}$ Helen Basturkmen, "Developing Courses in English for Specific Purposes,"

Developing Courses in English for Specific Purposes, 2010, 1-157, https://doi.org/10.1057/9780230290518.

${ }^{4}$ Hilma Pami Putri, "Analisa Kebutuhan Silabus Bahasa Inggris I Mahasiswa Perbankan Syariah Berbasis Esp," EKONOMIKA SYARIAH: Journal of Economic Studies 2, no. 2 (2018): 112, https://doi.org/10.30983/es.v2i2.663.
}

Al-Madrasah: Jurnal Ilmiah Pendidikan Madrasah Ibtidaiyah Vol. 6, No. 1, Januari-Maret 2022 
Riinawati : Perancangan Silabus ESP Program Studi Pendidikan Guru Madrasah Ibtidaiyah di UIN Antasari Banjarmasin

kualitas penelitian. Hal ini dibuat fleksibel untuk siswa oleh guru ${ }^{5}$. Silabus adalah bagian dari struktur universitas. Namun, tujuan atau kegunaan silabus di perguruan tinggi adalah sebagai mekanisme komunikasi, alat perencanaan bagi guru, rencana mata kuliah bagi pengguna, proses sosialisasi mahasiswa ke lingkungan akademik, dan kesempatan beasiswa bagi pengajar ${ }^{6}$.

Masalahnya terletak pada kenyataan bahwa banyak peneliti dan perancang silabus mengabaikan siswa sebagai sumber informasi dalam merancang silabus apa pun. Mereka fokus pada leksikon dan terjemahan tertentu dalam teks mereka. Perancang dan peneliti tersebut mencoba mengembangkan silabus mereka sesuai dengan tujuan mereka tanpa memperhatikan tujuan siswa dalam belajar bahasa Inggris.

Penelitian ini mencoba merancang silabus English Specific Purpose (ESP) untuk program Studi Pendidikan Guru Madrasah Ibtidayah di UIN Antasari Banjarmasin. Silabus ini diharapkan dapat memberikan kesempatan kepada siswa untuk menggunakan bahasa Inggris secara efektif. Begitu pula dengan kitab suci dan hadits di bawah ini yang menjelaskan tentang pendidikan.

"Allah akan meninggikan orang-orang yang beriman di antara kamu dan orang-orang yang diberi ilmu beberapa derajat." (Al-Mujadalah ayat 11)

"Barangsiapa menempuh jalan menuntut ilmu, maka Allah akan memudahkan baginya masuk surga.” (HR.Muslim)

Di Madrasah Ibtidayah Pendidikan Guru, kebutuhan belajar bahasa Inggris adalah kosakata dan berbicara karena mereka ingin mengetahui dan mengakses informasi dalam bahasa Inggris. Dan di Pendidikan Guru Madrasah Ibtidayah, dosen mengajar tentang bahasa Inggris umum, dan dosen tidak mengajar tentang bahasa Inggris khusus. Seberapa penting merancang silabus? Pembuatan silabus sangat penting karena merupakan pedoman atau model untuk mengembangkan pembelajaran dan mengelola kegiatan pembelajaran dan menyediakan sumber daya silabus yang merata untuk melakukan penilaian keberhasilan suatu program pembelajaran. Dan keistimewaan perancangan silabus di Prodi Pendidikan Guru Madrasah Ibtidayah adalah guru dapat mengajar dengan lebih baik tanpa khawatir akan keluar jalur, ruang lingkup materi, strategi pengajaran, atau keluar dari sistem evaluasi yang akan dibuat.

5 Muhammad Yaumi, "Pengembangan Bahan Ajar English for Specific Purpose Berbasis Tik," Lentera Pendidikan: Jurnal Ilmu Tarbiyah Dan Keguruan 15, no. 2 (2012): 144-60, https://doi.org/10.24252/lp.2012v15n2a2.

6 Eva Rosita, "Analisis Kebutuhan Bahasa Inggris Guru Kelas," Seminar Nasional Pendidikan FKIP UNTIRTA 2017, 2017, 417-24.

Al-Madrasah: Jurnal Ilmiah Pendidikan Madrasah Ibtidaiyah Vol. 6, No. 1, Januari-Maret 2022 
Riinawati : Perancangan Silabus ESP Program Studi Pendidikan Guru Madrasah Ibtidaiyah di UIN Antasari Banjarmasin

\section{METODE PENELITIAN}

Penelitian ini dikategorikan sebagai Research and Development (R\&D). Metode penelitian dan pengembangan $(\mathrm{R} \& \mathrm{D})$ menghasilkan produk tertentu dan menguji efektivitas produk. Dalam menciptakan produk, peneliti terlebih dahulu menganalisis kebutuhan, mendesain produk, dan mendorong keefektifannya dengan menggunakan penilaian ahli dan persepsi siswa ${ }^{7}$. Produk yang dihasilkan dalam penelitian ini adalah Silabus Esp Prodi Pendidikan Guru Madrasah Ibtidayah. Desain penelitian ini menggunakan model ADDIE. Model penelitian dan pengembangan model ADDIE terdiri dari 5 tahap, yaitu; Analisis, Desain, Pengembangan, Implementasi, dan Evaluasi ${ }^{8}$.

Analisis: Di sini, peneliti harus dapat mengetahui kekurangan, keinginan, dan juga kebutuhan siswa. Untuk mengetahuinya, ketiga komponen tersebut tertuang dalam angket yang penulis berikan untuk Program Studi Pendidikan Guru Madrasah Ibtidayah. Kuesioner juga bertujuan untuk mengetahui kompetensi siswa, kemampuan belajar siswa, pengetahuan siswa sebelumnya tentang Bahasa Inggris untuk Pendidikan Guru Madrasah Ibtidayah. Desain: Penulis merancang course grid untuk merencanakan pembelajaran bahasa Inggris untuk Pendidikan Guru Madrasah Ibtidayah. Kotak kursus berisi kebutuhan dan target pelajar-keterampilan khusus siswa, bagaimana materi disampaikan, dan bagaimana mereka tahu tentang bahasa Inggris. Pengembangan: Fase ini adalah tempat desainer dan pengembang instruksional membuat dan merakit aset konten yang telah dicetak biru dalam fase desain. Implementasi: Selama fase implementasi, prosedur untuk melatih fasilitator dan peserta dikembangkan. Pelatihan harus mencakup banyak hal (kurikulum, hasil belajar, metode penyampaian, dan prosedur pengujian). Evaluasi: Fase ini terdiri dari dua bagian: formatif dan sumatif. Penilaian konstruktif hadir di setiap tahap proses ADDIE. Sementara itu, penilaian sumatif terdiri dari tes yang dirancang untuk item referensi terkait kriteria domain-spesifik. Ini memberikan peluang untuk umpan balik dari pengguna yang mengidentifikasi.

Subyek penelitian ini adalah mahasiswa semester I Program Studi Pendidikan Guru Madrasah Ibtidaiyah UIN Antasari Banjarmasin.

7 M.A Dr. Sandu Siyoto, SKM., M.Kes \& Ali Sodik, Dasar Metodologi Penelitian, ed. Ayup, วารสารสังคมศาสตร์วิชาการ, vol. 7 (Karanganyar: Literasi Media Publishing, 2015).

${ }^{8}$ Abu \& Narbuko Achmadi, "Teori Metodologi Penelitian," Teori Metodologi Penelitian, 2011, 1-21. 
Riinawati : Perancangan Silabus ESP Program Studi Pendidikan Guru Madrasah Ibtidaiyah di UIN Antasari Banjarmasin

Dalam penelitian ini, data akan dikumpulkan sebanyak tiga kali dengan menggunakan kuesioner. Pertama adalah angket dalam need analysis, yang kedua adalah angket dalam expert judgement, dan yang terakhir adalah angket dalam uji coba (persepsi siswa).

\section{HASIL DAN PEMBAHASAN}

ESP adalah gerakan yang berupaya melayani kebutuhan bahasa pelajar yang membutuhkan bahasa Inggris untuk menjalankan peran tertentu (misalnya, mahasiswa, insinyur, perawat) dan yang membutuhkan untuk memperoleh konten dan keterampilan dunia nyata melalui media itu daripada menguasai bahasa untuk itu, dan ESP termasuk pendidikan, pelatihan, dan praktik dan mencakup tiga realisme pengetahuan yang signifikan, yaitu: bahasa, pedagogi, dan peserta pelatihan bidang minat khusus siswa ${ }^{9}$.

Bahasa Inggris untuk tujuan tertentu (ESP) harus dibagi menjadi dua macam, yaitu: empat karakteristik fundamental dan dua variabel. Empat atribut penting ESP terdiri dari pengajaran bahasa Inggris (1) Desain untuk memenuhi kebutuhan khusus. (2). Terkait dengan konten dengan disiplin ilmu, pekerjaan, dan kegiatan tertentu. (3). Berpusat pada bahasa yang sesuai dengan kegiatankegiatan dalam sintaksis, leksis, wacana, semantik, dll, dan analisis wacana ini. (4). Buatlah berbeda dari bahasa Inggris umum. Adapun ciri-ciri variabelnya antara lain: (1). Buat garis tentang keterampilan bahasa yang akan dipelajari (misalnya, membaca saja). (2). Tidak mengajarkan satu pengetahuan tertentu ${ }^{10}$.

Pendidikan Guru Madrasah Ibtidayah merupakan salah satu jurusan yang diselenggarakan oleh universitas. PGMI mempersiapkan peserta didik untuk memasuki dunia profesional pendidikan dasar, baik madrasah ibtidaiyah (MI) maupun sekolah dasar (SD). Dan bertujuan untuk menghasilkan lulusan yang kompeten, menjadi guru kelas, dan mengembangkan ilmu pengetahuan yang inovatif ${ }^{11}$. Madrasah Ibtidaiyah (MI) merupakan jenjang pendidikan formal paling dasar di Indonesia, setara dengan sekolah dasar yang dikelola Kementerian Agama. Pendidikan Madrasah Ibtidaiyah ditempuh dalam enam

${ }^{9}$ Melinda Roza, "Esp Dalam Pembelajaran Bahasa Inggris Di Ptai," Ijtimaiyya 6, no. 2 (2013): 143-56.

10 Jack C. Richards and Manel Lacorte, Book Reviews: Curriculum Development in Language Teaching, RELC Journal, vol. 33, 2002, https://doi.org/10.1177/003368820203300112.

${ }^{11}$ Muhamad Nur, "Penerapan Esp Di Perguruan Tinggi Umum (Non English Majors) Melalui Pendekatan Content-Based Instruction-Cbt," Mabasan 12, no. 1 (2018): 86-103, https://doi.org/10.26499/mab.v12i1.39.

Al-Madrasah: Jurnal Ilmiah Pendidikan Madrasah Ibtidaiyah

Vol. 6, No. 1, Januari-Maret 2022 
Riinawati : Perancangan Silabus ESP Program Studi Pendidikan Guru Madrasah Ibtidaiyah di UIN Antasari Banjarmasin

tahun, dari kelas 1 hingga kelas 6. Lulusan Madrasah Ibtidaiyah dapat melanjutkan mengajar ke madrasah tsanawiyah atau sekolah menengah pertama 12 .

Di Madrasah Ibtidaiyah Program Studi Pendidikan Guru merupakan mata pelajaran yang kritis karena siswa belajar bahasa Inggris hanya di semester pertama. Selain itu, siswa juga belajar tentang bahasa Inggris umum. Salah satu pendekatan dasar untuk mengembangkan materi bahasa Inggris adalah English Specific Purpose (ESP).

Penelitian ini difokuskan pada perancangan silabus bahasa Inggris untuk siswa Pendidikan Guru Madrasah Ibtidaiyah, dan pembuatan model ADDIE. Itu terdiri dari lima langkah. Langkah pertama yang peneliti lakukan adalah analisis dengan melakukan analisis kebutuhan, yang disajikan dalam bentuk angket yang berisi tentang kebutuhan, kekurangan, keinginan, dan setting siswa.

Setelah siswa menjawab angket, tahap selanjutnya adalah merancang produk, mereka membedakan antara dua kelompok kebutuhan: (1) kebutuhan target (yaitu, apa yang perlu dilakukan pembelajar dalam situasi target) dan (2) kebutuhan belajar (yaitu, bagaimana pelajar dapat memperoleh bahasa yang diperlukan dalam kasus seperti itu). Ini dibagi lagi ke dalam subkategori. Dengan demikian, kebutuhan kekurangan dan keinginan termasuk dalam kebutuhan sasaran, sedangkan strategi dan kendala belajar merupakan bagian dari kebutuhan belajar.

Tahap selanjutnya adalah pengembangan produk. Pada langkah ini, peneliti membuat silabus melalui beberapa pengukuran seperti tingkat kemahiran bahasa Inggris, topik yang menarik, target siswa, materi input, aktivitas, dan setting. Setelah menyusun silabus, tahap selanjutnya adalah melakukan validasi produk, produk, dan validasi yang dilakukan oleh tiga ahli desain, bahasa, dan materi. Tujuan verifikasi adalah untuk melihat kualitas silabus berdasarkan aspek validitas. Seorang ahli materi pelajaran melakukan validasi. Dalam proses validasi ini, ahli melakukan penilaian terhadap kuesioner. Kuesioner untuk ahli materi terdiri dari empat aspek: isi silabus, bahasa yang digunakan dalam silabus, masukan materi dalam silabus, desain,

12 Muhammad Ridlo Yuwono, "Analisis Kesulitan Mahasiswa Dalam Menyelesaikan Soal Geometri Berdasarkan Taksonomi Bloom Dan Alternatif Pemecahannya," Beta Jurnal Tadris Matematika 9, no. 2 (2016): 111, https://doi.org/10.20414/betajtm.v9i2.7.

Al-Madrasah: Jurnal Ilmiah Pendidikan Madrasah Ibtidaiyah Vol. 6, No. 1, Januari-Maret 2022 
Riinawati : Perancangan Silabus ESP Program Studi Pendidikan Guru Madrasah Ibtidaiyah di UIN Antasari Banjarmasin

dan tata letak dalam silabus. Setelah itu, peneliti mengoreksi silabus sesuai dengan revisi validator.

Tahap selanjutnya adalah implementasi dan evaluasi produk. Pada tahap ini dilakukan revisi silabus berdasarkan penilaian ahli yang telah diujikan atau persepsi siswa. Peneliti memanfaatkan metode persepsi siswa dengan membagikan link yang berisi aspek-aspek penting dari nilai silabus. Dilihat dari persepsi siswa, silabus sudah tersedia di Prodi Pendidikan Guru Madrasah Ibtidaiyah.

Selanjutnya, merancang silabus ESP untuk Siswa Irak di Sekolah Tinggi Pendidikan Jasmani”. Studi ini merupakan upaya untuk merancang silabus ESP untuk Siswa Irak di Sekolah Tinggi Pendidikan Jasmani. Kursus bahasa Inggris saat ini di Kolese ini mengadopsi metode pengajaran lama dan tradisional, yang terutama berfokus pada struktur bahasa Inggris dan poin-poin terpisah. Pada saat yang sama, silabus yang diusulkan dirancang sesuai dengan kebutuhan dan minat siswa.

Kuesioner yang digunakan terdiri dari 21 pernyataan. Dan angket persepsi siswa yang digunakan terdiri dari 10 pernyataan. Tujuan dari persepsi siswa adalah untuk melihat kualitas silabus bahasa Inggris berdasarkan aspek validitas. Desain silabus bahasa Inggris untuk Prodi Pendidikan Guru Madrasah Ibtidaiyah menyebabkan tidak adanya materi utama, dan tidak ada materi bahasa Inggris untuk PGMI secara khusus. Akibatnya, siswa tidak mahir berkomunikasi bahasa Inggris untuk PGMI sementara kebutuhan siswa di masa depan. Keterbatasan penelitian adalah, pelaksanaan tes dan evaluasi silabus hanya dilakukan pada satu semester di Program Studi Pendidikan Guru Madrasah Ibitidaiyah UIN Antasari Banjarmasin, hampir peneliti menggunakan google form, dan persepsi siswa menggunakan google form dan hanya 25 mata pelajaran.

Siswa kurang mahir berkomunikasi karena pada saat peneliti melakukan wawancara, mahasiswa S1 tersebut mengatakan bahwa mereka tidak dapat berkomunikasi dengan baik dalam bahasa Inggris, maka dari itu peneliti memaparkan silabus khusus mengenai pembelajaran bahasa Inggris dan dikaitkan dengan Program Studi Pendidikan Guru Madrasah Ibtidaiyah itu sendiri.

Pembelajaran bahasa Inggris di kelas diharapkan dapat mengembangkan baik pengetahuan maupun keterampilan siswa dalam menggunakan bahasa dalam tindakan komunikasi yang melibatkan empat keterampilan berbahasa yaitu mendengarkan (listening), berbicara (speaking), 
Riinawati : Perancangan Silabus ESP Program Studi Pendidikan Guru Madrasah Ibtidaiyah di UIN Antasari Banjarmasin

membaca (reading), dan menulis (menulis). Keterampilan terpadu merupakan cara pasif memandang keempat keterampilan berbahasa sebagai satu kesatuan dan terfragmentasi.

\section{KESIMPULAN}

English for Specific Purposes (ESP) adalah pendekatan yang berpusat pada peserta didik untuk mengajar bahasa Inggris sebagai bahasa tambahan, yang berfokus pada pengembangan kompetensi komunikatif dalam disiplin tertentu seperti akademik, akuntansi, agrologi, bisnis, TI, pengajaran, dan teknik.

Silabus bahasa Inggris yang sesuai untuk mahasiswa semester I Program Studi Pendidikan Guru Madrasah Ibtidaiyah meliputi beberapa komponen: (1) Tujuan pembelajaran bahasa Inggris bagi Program Studi Pendidikan Guru Madrasah Ibtidaiyah adalah guru SD/Madrasah Ibtidaiyah dan untuk berkomunikasi baik lisan maupun tulisan menggunakan bahasa Inggris dalam Pendidikan Guru Madrasah Ibtidaiyah. (2) Materi pembelajaran: Materi bahasa Inggris adalah bahasa Inggris dasar dan kosa kata termasuk part of speech, auxiliary verb (to be, to do, dll). Materi Madrasah Ibtidaiyah meliputi, pengenalan diri, salam, keluarga, rumah, sekolah, makanan dan minuman, binatang, mengungkapkan perasaan, waktu bercerita, profesi, dan dongeng. (3) metodologi pembelajaran adalah pembelajaran berbasis tugas. (4) Media pembelajaran berupa: video, gambar, audio, buku cerita.

\section{SARAN dan REKOMENDASI}

Berdasarkan kesimpulan di atas, peneliti ingin memberikan saran sebagai berikut:

1. Disarankan kepada dosen yang mengajar bahasa Inggris untuk pendidikan guru Madrasah Ibtidaiyah untuk menggunakan produk ini sebagai silabus utama dalam mengajar bahasa Inggris untuk PGMI pada semester pertama.

2. Disarankan kepada peneliti selanjutnya untuk melanjutkan penelitian ini. Sedang mengembangkan buku materi bahasa Inggris untuk pendidikan guru madrasah ibtidayah yang mengacu pada bahasa Inggris pada silabus yang dirancang ini.

\section{DAFTAR PUSTAKA}

Achmadi, Abu \& Narbuko. "Teori Metodologi Penelitian." Teori Metodologi 
Riinawati : Perancangan Silabus ESP Program Studi Pendidikan Guru Madrasah Ibtidaiyah di UIN Antasari Banjarmasin

Penelitian, 2011, 1-21.

Basturkmen, Helen. "Developing Courses in English for Specific Purposes." Developing Courses in English for Specific Purposes, 2010, 1-157. https://doi.org/10.1057/9780230290518.

Dr. Sandu Siyoto, SKM., M.Kes \& Ali Sodik, M.A. Dasar Metodologi Penelitian. Edited by Ayup. วารสารสังคมศาสตร์ชิชาการ. Vol. 7. Karanganyar: Literasi Media Publishing, 2015.

Nur, Muhamad. "Penerapan Esp Di Perguruan Tinggi Umum (Non English Majors) Melalui Pendekatan Content-Based Instruction-Cbt." Mabasan 12, no. 1 (2018): 86-103. https://doi.org/10.26499/mab.v12i1.39.

Oktradiksa, Ahwy. "Islamic Learning in English Academic Purpose," no. May (2016): 1-151.

Putri, Hilma Pami. "Analisa Kebutuhan Silabus Bahasa Inggris I Mahasiswa Perbankan Syariah Berbasis Esp." EKONOMIKA SYARIAH: Journal of $\begin{array}{llllll}\text { Economic Studies } & 2, & \text { no. } & 2 & \text { (2018): } & 112 .\end{array}$ https://doi.org/10.30983/es.v2i2.663.

Richards, Jack C., and Manel Lacorte. Book Reviews : Curriculum Development in Language Teaching. RELC Journal. Vol. 33, 2002. https://doi.org/10.1177/003368820203300112.

Rosita, Eva. "Analisis Kebutuhan Bahasa Inggris Guru Kelas." Seminar Nasional Pendidikan FKIP UNTIRTA 2017, 2017, 417-24.

Roza, Melinda. "Esp Dalam Pembelajaran Bahasa Inggris Di Ptai." Ijtimaiyya 6, no. 2 (2013): 143-56.

Yaumi, Muhammad. "Pengembangan Bahan Ajar English for Specific Purpose Berbasis Tik." Lentera Pendidikan : Jurnal Ilmu Tarbiyah Dan Keguruan 15, no. 2 (2012): 144-60. https://doi.org/10.24252/lp.2012v15n2a2.

Yulientinah, Dewi Selviani, Rukmi Juwita, and Widia Resdiana. "Identifikasi Analisis Kebutuhan Pembelajaran Bahasa Inggris (Non Program Studi Bahasa Inggris) Pada Mata Kuliah Bahasa Inggris Khusus/ English For Specific Purposes (ESP) Di Program Studi D4 Akuntansi Keuangan Politeknik Pos Indonesia." Competitive 15, no. 1 (2020): 1-11. https://doi.org/10.36618/competitive.v15i1.625.

Yuwono, Muhammad Ridlo. "Analisis Kesulitan Mahasiswa Dalam Menyelesaikan Soal Geometri Berdasarkan Taksonomi Bloom Dan Alternatif Pemecahannya." Beta Jurnal Tadris Matematika 9, no. 2 (2016): 111. https://doi.org/10.20414/betajtm.v9i2.7.

Al-Madrasah: Jurnal Ilmiah Pendidikan Madrasah Ibtidaiyah

Vol. 6, No. 1, Januari-Maret 2022 